\title{
Growth analysis of preterm newborns with gastroschisis during hospitalization in a Neonatal Intensive Care Unit
}

\author{
Juliana Zoboli Del BIGIO, Mário Cícero FALCÃO and Ana Cristina Aoun TANNURI
}

Received: 7 May 2021 Accepted: 18 June 2021

\begin{abstract}
Background - Gastroschisis, especially complex type, prematurity and low birth weight are associated with a worse clinical outcome with higher mortality, higher incidence of sepsis and catheter-related infection, cholestasis, short bowel syndrome, greater number of days to achieve full diet, longer time of parenteral nutrition and longer hospitalization time. Objective - To evaluate the growth of preterm newborns with gastroschisis during their hospitalization in the neonatal intensive care unit. Methods - Descriptive study, based on a retrospective cohort (January 2012 to December 2018), including preterm newborns (gestational age less than 37 weeks) with simple and complex gastroschisis admitted in a tertiary neonatal intensive care unit. The following parameters were analyzed: maternal age, parity, type of delivery, birth weight, gender, gestational age, nutritional adequacy, type of gastroschisis, fasting time, parenteral nutrition time, time until achieving full enteral nutrition, hospitalization time, weight gain and outcome. The results were expressed in percentage, average, and median. Results - A total of 101 newborns with gastroschisis were admitted, of which $59.4 \%$ were premature ( $80.7 \%$ of late preterm infants). From the maternal data, the mean age was 21.2 years and $68.3 \%$ were primiparous. Regarding childbirth: $80 \%$ were cesarean sections. From newborns: the average birth weight was $2137 \mathrm{~g}, 56.6 \%$ were female, the average gestational age was 34.8 weeks, the average weight gain was $20.8 \mathrm{~g} /$ day during hospitalization and $83.3 \%$ were discharged from the hospital. Conclusion - The growth analysis by weight gain (grams/day) during hospitalization in the intensive care unit showed that more than $90 \%$ of the sample presented acceptable or adequate weight gain.
\end{abstract}

Keywords - Gastroschisis; infant, premature; growth; infant, newborn.

\section{INTRODUCTION}

Gastroschisis is a defect of the abdominal wall, in most cases to the right of the umbilical cord insertion. Intestinal loops and occasionally parts of other abdominal organs burst out the defect of the abdominal wall, without membranes or sac covering the viscera $^{(1)}$. Genetic polymorphism, interaction with environmental factors such as smoking and maternal age below 20 years may play a role in the pathogenesis of this disease ${ }^{(2)}$.

The prevalence of gastroschisis has been increasing worldwide since 1995, reaching three to four cases for 10,000 live births, with no difference between genders ${ }^{(3)}$. Hypotheses for the cause of gastroschisis include failure of mesodermal formation in the abdominal wall, rupture of the amniotic membrane around the umbilical ring, sequelae of right umbilical vein involution, or interruption of the right calf $\operatorname{artery}^{(4)}$.

Gastroschisis can be classified as simple when it occurs as an isolated defect and complex, when associated with intestinal anomalies such as intestinal atresias, perforations, necrotic segments or volvolus ${ }^{(4)}$.

Gastroschisis, especially complex type, prematurity and low birth weight are associated with a worse clinical outcome with higher mortality, higher incidence of sepsis and catheter-related infection, cholestasis, short bowel syndrome, greater number of days to achieve full diet, longer time of parenteral nutrition and longer hospitalization time ${ }^{(5)}$. Prolonged dependence on parenteral nutrition can trigger liver disease associated with parenteral nutrition, with possible progression to severe liver failure ${ }^{(6)}$.

Gastroschisis increases the risk of preterm labor, and only $35 \%$ of deliveries occur with gestational age equal to or greater than 37 weeks $^{(7)}$.

Parenteral nutrition has become part of the daily clinical treatment of several patients requiring nutritional supplementation. In newborns, parenteral nutrition contributed to improve the survival of preterm infants, including congenital bowel anomalies.

Currently, newborns with gastroschisis, both premature and term, require early and balanced parenteral nutrition to survive periods of fasting, which the underlying disease itself determines, because intestinal dysmotility associated with gastroschisis is well known, in both situations simple and complex defect.

It is also known that newborns receiving parenteral nutrition have lower energy needs than those in enteral nutrition, due to lower intestinal losses, exclusion of digestion and absorption processes and dynamic-specific action of food. A non-protein supply of 60 
$\mathrm{kcal} / \mathrm{kg}$, associated with an adequate supply of amino acids, meets the rest metabolic needs of the newborn. With caloric offers of $80-90 \mathrm{kcal} / \mathrm{kg}$ and protein of $3 \mathrm{~g} / \mathrm{kg} / \mathrm{day}$, some increase in weight and growth is already observed. Thus, in newborns with gastroschisis, total parenteral nutrition with $3-4 \mathrm{~g} / \mathrm{kg} /$ day of protein and $100 \mathrm{kcal} / \mathrm{kg} /$ day of non-protein calories, maintaining a non-protein nitrogen/calorie ratio of around $1 / 150$ to $1 / 200$, promotes anabolism and adequate growth of these newborns ${ }^{(8)}$.

Despite this therapeutic arsenal in parenteral nutritional therapy, studies show that newborns, mainly preterm with associated diseases, do not present expected weight gain based on currently growth charts ${ }^{(9)}$.

Potential clinical effects of this growth failure include increased stay in the neonatal intensive care unit and worse outcomes in neurodevelopment. There is also evidence showing a link between inadequate early neonatal nutrition and health outcomes, including increased cardiovascular disease, obesity and diabetes ${ }^{(8)}$.

The numerical methods used to describe the growth rate of preterm newborns in relation to weight, length and head circumference include grams/kg/day (g/kg/d), grams/day (g/d), centimeters/ week $(\mathrm{cm} / \mathrm{w})$ and $\mathrm{z}$-score evaluation ${ }^{(10)}$.

From the above, there are difficulties in adequately nourishing preterm infants with gastroschisis, as well as there are difficulties in measuring this nutrition, that is, in measuring an adequate growth.

Thus, the aim of the present study is to evaluate the growth of preterm newborns with simple and complex gastroschisis during their hospitalization in the neonatal intensive care unit.

\section{METHODS}

This is a descriptive study, based on a retrospective cohort, including preterm newborns (gestational age less than 37 weeks) with simple and complex gastroschisis, admitted to the Neonatal Intensive Care Center 2 (CTIN-2) of the Child and Adolescent Institute of the Clinics Hospital - Faculty of Medicine - University of São Paulo (HC-FMUSP), Brazil, from January 2012 to December 2018.

CTIN-2 is a Neonatal Intensive Care Unit tertiary-level that provides care to high complexity newborns. The criterion of hospitalization in this center consists of newborns and young infants under 45 days of life who require clinical and surgical intensive care. In recent years, gastroschisis was the second surgical pathology with the highest number of hospitalizations.

The neonatology, child surgery, hospital infection control commission, physiotherapy, nursing and nutrition teams developed a managed protocol to care the newborn with gastroschisis.

Parenteral nutrition is initiated on the first days of life if the newborn has hemodynamic stability. The nutritional target in total parenteral nutrition is 3 to $3.5 \mathrm{~g} / \mathrm{kg} /$ day of amino acids, $3 \mathrm{~g} / \mathrm{kg} /$ day of lipids, preferably with fish oil and glucose infusion rate of 12 $\mathrm{mg} / \mathrm{kg} /$ minute $^{(11)}$. The volume is titrated from daily water balance and electrolytes and micronutrients are prescribed based on basic needs and serial laboratory evaluation.

The venous access of choice is the peripherally inserted central catheter (PICC) and is maintained with rigorous antisepsis techniques, with standardized dressing switching and proper manipulation, to avoid catheter-associated infection.

The onset of enteral diet occurs when gastric residue is in reduction and the appearance becomes yellow or salivary. Breast milk is the diet of choice and starts with $20 \mathrm{~mL} / \mathrm{kg}$, with daily increase of the diet, until reaching the full diet. When fasting is longer than 30 days, it is chosen to start the diet with hydrolyzed formula in the absence of breast milk.

The project was approved by the Ethics Committee of the Department of Pediatrics and the Research Project Analysis Committee (CAPPesq) of HC-FMUSP, protocol 2476188, and the Informed Consent Form was waived because it is a collection of data from the medical records of these newborns.

The following items were collected from medical records: maternal age (years); parity (primiparous or not); type of delivery (vaginal or cesarean); birth weight (grams); gender; gestational age (weeks), calculated by fetal ultrasound up to 20 weeks of gestation $^{(12)}$, for subsequent classification of prematurity; nutritional adequacy (small - below the 10th percentile, adequate - between 10th and 90th percentiles or large for gestational age - above the 90th percentile), using Fenton curves (2013) (13); type of gastroschisis (simple or complex) - diagnosed during surgery; fasting time (days), time of parenteral nutrition (days); time until reaching full enteral nutrition (minimum volume of $120 \mathrm{~mL} / \mathrm{kg} /$ day of enteral diet) (14) $^{(14)}$ (days); hospitalization time (days); weight gain from hospitalization to discharge (grams/day), and outcome (hospital discharge or death).

For the evaluation of the growth of these preterm infants with gastroschisis through weight, the criterion of increasing or decreasing daily weight in grams/day was adopted from hospitalization to hospital discharge ${ }^{(10)}$. Adequate gain was considered values higher than 15 grams/day, acceptable values between 10 and 15 grams/day and inadequate values, less than 10 grams/day. For this study, the Fenton growth curves were chosen to classify the newborn after birth and in the follow-up period, and the weight gain in gram/ day criterion was chosen. Newborns are weighed daily on digital scales and calibrated, naked and always by a nurse. The justification for choosing the grams/day criterion to evaluate the growth of these preterm infants was based on a systematic review, published in 2017, where the methods for this evaluation were studied. It was evaluated 373 studies from England, France, Germany and Spain and the most used criteria to calculate the weight gain of preterm newborns were: gram $/ \mathrm{kg} / \mathrm{day}$, in $40 \%$ of the publications, followed by gram/day, $32 \%$, and $29 \%$ used changes in the $\mathrm{z}$ score in intrauterine and postnatal growth charts, however, the authors do not present definitive conclusions regarding the best method for this evaluation ${ }^{(10)}$.

In a study published in 2017 studying weight gain in preterm infants by the grams/day criterion, daily increments of 12 to 16 $\mathrm{g} /$ day were observed ${ }^{(15)}$, justifying the choice, in this research, of inadequate values (less than $10 \mathrm{~g} /$ day), acceptable (between 10 and $15 \mathrm{~g} /$ day) and adequate (greater than $15 \mathrm{~g} /$ day).

The classification of prematurity adopted was very premature (gestational age between 28 and 32 weeks) and, moderate preterm infants (gestational age between 32 and 37 weeks, including late preterm infants - gestational age between 34 and 37 weeks); in relation to birth weight (extreme low birth weight - birth weight less than $1000 \mathrm{~g}$, very low birth weight - birth weight between 1000 and $1500 \mathrm{~g}$, low birth weight between 1500 and $2500 \mathrm{~g}$ and birth weight greater than $2500 \mathrm{~g}$ ), and nutritional adequacy (small, adequate, or large for gestational age, according to the reference curve adopted) $)^{(10)}$.

The results are expressed in proportions, average with standard deviation and median, with minimum and maximum values. The sample size was not calculated because it is a convenience sample. 


\section{RESULTS}

During the study period, from January 2012 to December 2018, 101 newborns with gastroschisis were admitted, with an admission rate of 14.4 newborns/year. Of these, 60 newborns $(59.4 \%)$ were premature (gestational age less than 37 weeks).

TABLE 1 shows the variables studied in this group of preterm infants, expressed in proportions, averages and standard deviation or medians, with minimum and maximum values.

TABLE 2 describes the classification of prematurity. $80.7 \%$ were late preterm infants, $18.3 \%$ were small for gestational age and $71.8 \%$ were low birth weight.

TABLE 3 shows the weight gain of this group of preterm infants by the criterion of grams/day, being adequate gain values higher than $15 \mathrm{~g} /$ day, acceptable values between 10 and $15 \mathrm{~g} /$ day, and inadequate values, less than $10 \mathrm{~g} /$ day.

\section{DISCUSSION}

This study presents two extremely important aspects that have not yet been addressed in the literature. The first is to analyze a cohort of gastroschisis composed only of preterm newborns, because published studies on gastroschisis cohorts analyze premature and term infants together ${ }^{(16,17)}$. The second is to describe the growth of these preterm infants, because there are few studies that analyze growth and not only with preterm newborns ${ }^{(9)}$.

The prematurity rate analyzed in this cohort was $59.4 \%$, with a mean gestational age of 34.8 weeks. A recent study published in 2020 analyzing 566 newborns with gastroschisis in eight tertiary

TABLE 1. Variables studied $(\mathrm{n}=60)$.

\begin{tabular}{|c|c|}
\hline Variable & $\mathrm{n}$ \\
\hline Maternal age (years) & $21.20 \pm 1.41 *$ \\
\hline Primiparous & $41(68.33 \%)$ \\
\hline \multicolumn{2}{|l|}{ Type of delivery } \\
\hline Vaginal & $12(20.0 \%)$ \\
\hline Caesarian & $48(80.0 \%)$ \\
\hline Birth weight (grams) & $2137.61 \pm 414.46 *$ \\
\hline \multicolumn{2}{|l|}{ Gender } \\
\hline Female & $32(53.33 \%)$ \\
\hline Male & $28(46.67 \%)$ \\
\hline Gestational age (weeks) & $34.80 \pm 3.90 *$ \\
\hline \multicolumn{2}{|l|}{ Type of gastroschisis } \\
\hline Simple & $49(81.66 \%)$ \\
\hline Complex & $11(18.34 \%)$ \\
\hline Fasting time (days) & $27 * *($ minimum 7, maximum 105$)$ \\
\hline $\begin{array}{l}\text { Parenteral nutrition } \\
\text { time (days) }\end{array}$ & $30.50 * *$ (minimum 7, maximum 125 ) \\
\hline $\begin{array}{l}\text { Time to achieve full } \\
\text { enteral diet (days) }\end{array}$ & $36.50 * *$ (minimum 15, maximum 134$)$ \\
\hline Hospital stay (days) & $39.50 * *$ (minimum 7, maximum 138 ) \\
\hline Weight gain (grams/day) & $20.84 \pm 6.57$ \\
\hline \multicolumn{2}{|l|}{ Outcome } \\
\hline Discharged & $50(83.34 \%)$ \\
\hline Death & $10(16.66 \%)$ \\
\hline
\end{tabular}

TABLE 2. Classification of preterm newborns in relation to gestational age, birth weight and nutritional adequacy $(n=60)$.

\begin{tabular}{lc}
\hline Classification & $\mathrm{n}$ \\
\hline Gestational age* & \\
Very premature & $3(5.0 \%)$ \\
Moderate premature & $57(95.0 \%)$ \\
Late premature & $46(80.70 \%)$ \\
Birth weight** & \\
Extreme low birth weight & 0 \\
Very low birth weight & $3(5.0 \%)$ \\
Low birth weight & $43(71.77 \%)$ \\
Birth weight $>2500 \mathrm{~g}$ & $14(23.33 \%)$ \\
Nutritional adequacy*** & $11(18.33 \%)$ \\
Small for gestational age & $48(80.0 \%)$ \\
Adequate for gestational age & $1(1.67 \%)$ \\
Large for gestational age &
\end{tabular}

*Very premature - gestational age between 28 and 32 weeks, moderate preterm infants gestational age between 32 and 37 weeks) and late preterm infants - gestational age between 34 and 37 weeks). **Extreme low birth weight - birth weight less than $1000 \mathrm{~g}$, very low birth weight - birth weight between 1000 and $1500 \mathrm{~g}$, low birth weight between 1500 and $2500 \mathrm{~g}$ and birth weight greater than $2500 \mathrm{~g}) . * * *$ Small $(P<10)$, adequate $(P=10-90)$, or large for gestational age $(P>90)$

TABLE 3. Weight gain by grams/day criterion $(n=60)$.

\begin{tabular}{lc}
\hline Weight gain (grams/day) & $\mathbf{n}$ \\
\hline Inadequate gain (<10 grams/day) & $5(8.33 \%)$ \\
Acceptable gain (between 10 and 15 grams/day) & $5(8.33 \%)$ \\
Adequate gain (>15 grams/day) & $50(83.34 \%)$ \\
\hline
\end{tabular}

centers showed that gestational age at birth ranged from 28 to 40 weeks, with a median of 36 weeks and $56 \%$ were premature ${ }^{(18)}$.

Among the risk factors for gastroschisis, young and primiparous mothers stand out. This study showed an average of maternal age of 21.2 years, compatible with data from Eggink et al. (2006) ${ }^{(19)}$, who had an average of 19.3 years and Raymond et al. $(2020)^{(18)}$, with a median of 21 years. Regarding primiparous women, the findings were also in agreement with the literature, $68.3 \%$ in the present study, 68.7\% (Calcagnotto et al., 2013) ${ }^{(20)}$ and 60.8\% (Friedman et al., 2016) ${ }^{(7)}$.

Another fact that draws attention is the high rate of cesarean deliveries found $(80 \%)$, because there is no evidence that cesarean delivery improves the result of gastroschisis, especially with complications. The literature shows a rate around $50 \%{ }^{(18)}$. In Brazil, Calcagnotto et al., in Porto Alegre, studying the risk factors associated with mortality in newborns with gastroschisis, found a cesarean section rate of $92.2 \%{ }^{(20)}$. Elective preterm delivery before 37 weeks of gestation has been suggested to protect the externalized intestine from damage due to exposure to amniotic fluid, with consequent serositis and compressions, however, these studies still present conflicting results, therefore, surgical delivery is reserved only for obstetric indications ${ }^{(21)}$.

Of the 60 newborns studied, there was no predominance between genders in the incidence of gastroschisis (female $53.3 \%$ and male $46.7 \%$ ), a fact that is comparable to the literature, according to Mastroiacovo et al., 2007 ${ }^{(22)}$. The incidence of complex gastroschisis was $18.3 \%$, slightly higher when compared to the literature, which average of $14 \%{ }^{(18)}$. 
The median fasting time was 27 days, parenteral time, 30.5 days, and to achieve full enteral nutrition, 36.5 days, compatible with recently published data, showing median parenteral nutrition time of 27 to 30 days $^{(18)}$. Literature data with preterm infants smaller than $1500 \mathrm{~g}$ show a median of 67 days for parenteral nutrition and 107 days for full enteral nutrition ${ }^{(18)}$.

The intestinal dysmotility in gastroschisis is a common evolution with important interference in the beginning of enteral diet and need for prolonged parenteral nutrition time ${ }^{(23)}$. After surgical correction of gastroschisis, a period of intestinal hypomotility usually occurs, with spontaneous regression ${ }^{(24)}$.

The etiology of this transient intestinal dysfunction is not yet fully elucidated and may be related to a defect in the maturation of intestinal neurons. A Brazilian experimental study, published in $2003^{(24)}$, analyzing fetuses of rabbits with gastroschisis, showed that the intestinal plexus of fetuses with gastroschisis are more immature compared to controls. The irritating action of amniotic fluid is the most plausible explanation for this neuronal disorder of intestinal maturation ${ }^{(24)}$.

The median hospital stay was 39.5 days, like the literature, where the hospitalization time in three studies analyzed was 48 days (mean) ${ }^{(25)}, 33$ days (median) ${ }^{(26)}$ and 37 days (median) ${ }^{(18)}$. In preterm infants smaller than $1500 \mathrm{~g}$, the hospital stay in a recent publication was 77.5 days $^{(18)}$.

Regarding the outcomes (hospital discharge or death), mortality was $16.6 \%$, higher than the literature that is around $5 \%{ }^{(18)}$. This difference can be explained by inadequate prenatal care for pregnant women and a higher incidence of complex gastroschisis. In two Brazilian studies, one conducted at the Clinics Hospital of the Federal University of Minas Gerais and the other at the Clinics Hospital of Porto Alegre, mortality rates were $14.9 \%{ }^{(25)}$ and $23.4 \%{ }^{(20)}$, respectively. However, all these mortality rates are from cohorts that included preterm and term newborns.

The average birth weight was $2137.6 \mathrm{~g}$, with $5 \%$ very low birth weight, $71.7 \%$ low birth weight and $23.3 \%$ with birth weight greater than $2500 \mathrm{~g}$. Regarding nutritional adequacy: $18.3 \%$ small, $80 \%$ adequate and $1.7 \%$ large for gestational age, according to Fenton curves ${ }^{(14)}$, standardized in the service where the research was conducted.
It is known that an adequate fetal growth, especially in the third trimester of pregnancy, depends on a satisfactory physiology of the digestive tract, a fact that does not occur in gastroschisis, because there is loss of nutrients, especially proteins, due to intestinal exposure to amniotic fluid. This fact may lead to restriction of intrauterine growth and, consequently, small for gestational age newborns. However, in this study, a relatively small number of newborns small for gestational age were obtained (18.3\%), in agreement with another Brazilian study that showed $14.3 \%$, although this percentage included premature and term newborns ${ }^{(25)}$.

The evaluation of growth during hospitalization time, adopting the criterion of grams/day, showed an average weight gain of 20.8 $\mathrm{g} /$ day, distributed as well: $8.3 \%$ of the neonates had inadequate weight gain, considering less than $10 \mathrm{~g} /$ day, $8.3 \%$ had acceptable gain, between 10 and $15 \mathrm{~g} /$ day and the most (83.3\%), adequate gain, greater than $15 \mathrm{~g} /$ day.

\section{CONCLUSION}

In conclusion, the growth analysis of preterm newborns with simple and complex gastroschisis through the criterion of weight gain (grams/day) during hospitalization in a neonatal intensive care unit, showed that more than $90 \%$ of the sample presented acceptable weight gain (10 to $15 \mathrm{~g} /$ day) or adequate ( $>15 \mathrm{~g} /$ day), emphasizing that preterm newborns who do not gain weight in the neonatal intensive care unit remain hospitalized for longer, increasing morbidity and mortality, besides the risk of presenting cognitive deficits in the follow-up. In addition, prolonged hospitalizations substantially increase health costs.

\section{Authors' contribution}

Bigio JZD: data collection, research execution, text writing, statistical analysis. Falcão MC: data collection, research execution, text writing, statistical analysis. Tannuri ACA: research execution, text writing.

\section{Orcid}

Juliana Zoboli Del Bigio: 0000-0002-4326-2575.

Mário Cícero Falcão: 0000-0002-5658-3992.

Ana Cristina Aoun Tannuri: 0000-0002-5481-032X.

Bigio JZD, Falcão MC, Tannuri ACA. Análise do crescimento de recém-nascidos pré-termo com gastrosquise durante a Internação em Unidade de Terapia Intensiva Neonatal. Arq Gastroenterol. 2021;58(4):504-8.

RESUMO - Contexto - Gastrosquise, principalmente o tipo complexo, prematuridade e baixo peso ao nascer estão associados a um pior desfecho clínico com maior mortalidade, maior incidência de sepse e infecção relacionada ao cateter, colestase, síndrome do intestino curto, maior número de dias para atingir dieta plena, maior tempo de nutrição parenteral e maior tempo de internação. Objetivo - Avaliar o crescimento de recém-nascidos pré-termo com gastrosquise durante sua internação na unidade de terapia intensiva neonatal. Métodos - Estudo descritivo, baseado em uma coorte retrospectiva (janeiro de 2012 a dezembro de 2018), incluindo recém-nascidos pré-termo (idade gestacional inferior a 37 semanas) com gastrosquise simples e complexa, admitidos em uma unidade de terapia intensiva neonatal de nível terciário. Foram analisados: idade materna, paridade, tipo de parto, peso de nascimento, gênero, idade gestacional, adequação nutricional, tipo de gastrosquise, tempos de jejum, de nutrição parenteral, até atingir nutrição enteral plena e de internação, ganho de peso e desfecho. Os resultados estão expressos em porcentagem, médias e medianas. Resultados Foram admitidos 101 recém-nascidos com gastrosquise, dos quais 59,4\% eram prematuros ( $80,7 \%$ prematuros tardios). Dos dados maternos, a idade média foi de 21,2 anos e $68,3 \%$ eram primigestas. Com relação ao parto: $80 \%$ foram cesarianas. Dos recém-nascidos: o peso médio de nascimento foi de 2137 g, 56,6\% eram do sexo feminino, a idade gestacional média foi de 34,8 semanas, o ganho médio de peso de 20,8 g/dia durante a internação e $83,3 \%$ receberam alta hospitalar. Conclusão - A análise do crescimento por meio de ganho de peso (gramas/dia) durante a internação na unidade de terapia intensiva mostrou que mais de $90 \%$ da amostra apresentou ganho aceitável ou adequado de peso.

Palavras-chave - Gastrosquise; recém-nascido prematuro; crescimento; recém-nascido. 


\section{REFERENCES}

1. Prefumo F, Izzi C. Fetal abdominal wall defects. Best Pract Res Clin Obstet Gynaecol. 2014;28:391-402.

2. Torfs CP, Christianson RE, Iovannisci DM, Shaw GM, Lammer EJ. Selected gene polymorphisms and their interaction with maternal smoking, as risk factors for gastroschisis. Birth Defects Res A Clin Mol Teratol. 2006;76:723-30.

3. Jones AM, Isenburg J, Salemi JL, Arnold KE, Mai CT, Aggarwal D, et al. Increasing Prevalence of Gastroschisis-14 States, 1995-2012. MMWR Morb Mortal Wkly Rep. 2016;65:23-6

4. Bergholz R, Boettcher M, Reinshagen K, Wenke K. Complex gastroschisis is a different entity to simple gastroschisis affecting morbidity and mortality-a systematic review and meta-analysis. J Pediatr Surg. 2014;49:1527-32.

5. Raymond SL, Hawkins RB, St Peter SD, Downard CD, Qureshi FG, Renaud E, et al. Predicting Morbidity and Mortality in Neonates Born with Gastroschisis J Surg Res. 2020;245:217-24.

6. Dennison FA. Closed gastroschisis, vanishing midgut and extreme short bowe syndrome: Case report and review of the literature. Ultrasound. 2016;24:170-4.

7. Friedman AM, Ananth CV, Siddiq Z, D'Alton ME, Wright JD. Gastroschisis: epidemiology and mode of delivery, 2005-2013. Am J Obstet Gynecol. 2016;215:348. e1-9.

8. Bishay M, Lakshminarayanan B, Arnaud A, Garriboli M, Cross KM, Curry JI, et al. The role of parenteral nutrition following surgery for duodenal atresia or stenosis. Pediatr Surg Int. 2013;29:191-5.

9. Hall NJ, Drewett M, Burge DM, Eaton S. Growth pattern of infants with gastroschisis in the neonatal period. Clin Nutr ESPEN. 2019;32:82-7.

10. Fenton TR, Chan HT, Madhu A, Griffin IJ, Hoyos A, Ziegler EE, et al Preterm Infant Growth Velocity Calculations: A Systematic Review. Pediatrics 2017;139:e20162045.

11. Mihatsch WA, Braegger C, Bronsky J, Cai W, Campoy C, Carnielli V, et al. ESPGHAN/ESPEN/ESPR/CSPEN guidelines on pediatric parenteral nutrition. Clin Nutr. 2018;37:2303-5.

12. Cardoso LE, Falcão MC. Nutritional assessment of very low birth weight infants relationships between anthropometric and biochemical parameters. Nutr Hosp. 2007;22:322-9.

13. Fenton TR, Kim JH. A systematic review and meta-analysis to revise the Fenton growth chart for preterm infants. BMC Pediatr. 2013;13:59.
14. Hay WW. Optimizing nutrition of the preterm infant. Zhongguo Dang Dai Er Ke Za Zhi. 2017;19:1-21.

15. Evereklian M, Posmontier B. The Impact of Kangaroo Care on Premature Infant Weight Gain. J Pediatr Nurs. 2017;34:e10-e16.

16. Tannuri AC, Sbragia L, Tannuri U, Silva LM, Leal AJ, Schmidt AF, et al. Evolution of critically ill patients with gastroschisis from three tertiary centers. Clinics (Sao Paulo). 2011;66:17-20.

17. Lund $\mathrm{CH}$, Bauer K, Berrios M. Gastroschisis: incidence, complications, and clinical management in the neonatal intensive care unit. J Perinat Neonatal Nurs 2007;21:63-8.

18. Raymond SL, Hawkins RB, St Peter SD, Downard CD, Qureshi FG, Renaud E, et al. Predicting Morbidity and Mortality in Neonates Born with Gastroschisis Journal of Surgical Research. 2020;245:217-24

19. Eggink BH, Richardson CJ, Malloy MH, Angel CA. Outcome of gastroschisis: a 20-year case review of infants with gastroschisis born in Galveston, Texas. J Pediatr Surg. 2006;41:1103-8.

20. Calcagnotto H, Müller ALL, Leite JCL, Sanseverino MTV, Gomes KW, Magalhães JAA. Associated factors for perinatal mortality in gastroschisis. Rev Bras Ginecol Obstet. 2013;35:549-53

21. Puligandla PS, Janvier A, Flageole H, Bouchard S, Laberge JM. Routine cesarean delivery does not improve the outcome of infants with gastroschisis. J Pediatr Surg. 2004;39:742-5.

22. Mastroiacovo P, Lisi A, Castilla EE. The incidence of gastroschisis: research urgently needs resources. BMJ. 2006;332:423-4.

23. Fallon EM, Mitchell PD, Potemkin AK, Nehra D, Arsenault DA, Robinson EM, et al. Cholestasis and growth in neonates with gastroschisis. J Pediatr Surg. 2012;47:1529-36.

24. Santos MM, Tannuri U, Maksoud JG. Alterations of enteric nerve plexus in experimental gastroschisis: is there a delay in the maturation? J Pediatr Surg. 2003;38:1506-11.

25. Alves FMS, Iranda ME, De Aguiar MJB, Viana MCFB. Nutritional management and postoperative prognosis of newborns submitted to primary surgical repair of gastroschisis. J Pediatr (Rio). 2016;92:268-75.

26. Redondo AC, Feferbaum R, Vieira RA, Moreira DAR, Tannuri U, Carvalho WB, et al. Characteristics of the clinical development of a newborn with gastroschisis in an intensive care unit in Latin America. J Hum Growth Dev. 2016;26:190-8. 